\title{
Ability of Endogenous Folate from Soy Protein Isolate to Maintain Plasma Homocysteine and Hepatic DNA Methylation during Methyl Group Depletion in Rats
}

\author{
Richard K. Le LeU, * Graeme H. McIntosh ${ }^{1}$ and Graeme P. YounG ${ }^{2}$ \\ University of Adelaide, Department of Medicine, Adelaide, \\ South Australia 5000, Australia \\ ${ }^{1}$ CSIRO Division of Human Nutrition, Adelaide, \\ South Australia 5000, Australia \\ ${ }^{2}$ Department of Medicine, Flinders University, Bedford Park, \\ South Australia 5042, Australia
}

(Received December 15, 1997)

Summary We investigated different means of achieving methyl depletion by feeding weanling rats modified AIN diets depleted of folate (FD), folate + choline (FCD), and folate + choline + methionine (FCMD), and examined the consequent effects on folate status, homocysteine levels, and methylation status. Control rats were fed a $12 \%$ protein diet consisting of either casein or soy protein isolate (SPI) and containing $2 \mathrm{mg} / \mathrm{kg}$ folate, $0.2 \%$ choline, and $0.4 \%$ methionine. After the rats had been on the diets for 4 and 8 weeks, whole blood folate concentration was measured and found to be significantly depleted in the folate deficient treatments compared with controls at 4 weeks $(p<0.001)$, this reduction being significantly greater $(p<0.03)$ in casein-fed rats $(60 \%)$ than in SPI-fed rats $(32 \%)$. The omission of choline and methionine from the diet had no further influence on whole blood folate. A significant inverse correlation was observed in the casein-fed rats after 8 weeks between mean plasma homocysteine concentration and decreasing methyl content of the diet $\left(r^{2}=0.978\right.$, $p<0.002$ ), an effect not seen in the corresponding SPI-fed rats. Hypomethylation of hepatic DNA evidenced by a reduction in 5-methylcytosine content was present in the casein rats fed FCD and FCMD relative to control $(p<0.05)$. No hepatic DNA methylation changes were observed in the SPI-fed rats. The results obtained in the present work demonstrate that a soy-based diet can compensate against methyl group depletion by maintaining plasma homocysteine levels and an adequate level of DNA methylation, a result we attribute to endogenous folate content.

* To whom correspondence should be addressed at CSIRO, Division of Human Nutrition, Adelaide, South Australia 5000, Australia 
Key Words rat, folate, homocysteine, DNA methylation, soy protein

Dietary methyl group deficiency has been linked to the development of certain cancers $(1,2)$. The nutrients folate, methionine choline, and betaine are all capable of influencing the availability of labile methyl groups that subsequently play an important role in many processes, such as DNA synthesis and methylation. There is increasing evidence indicating that an abnormal DNA methylation pattern may play a role in the progression of human cancers $(3,4)$.

The objective of the present study was to investigate the effect of feeding rats a folate deficient diet (FD) alone and with superimposed choline and methionine deficiencies on a whole blood folate concentration and hepatic DNA methylation status. Other parameters related to folate metabolism that were studied included plasma homocysteine concentration. The progressive depletion of dietary methyl donors was designed to assess the degree of severity of methyl group depletion in these modified AIN diet preparations. These diets were based on the AIN-76A formula (5), but modified to contain either casein or soy protein isolate (SPI) as the base protein source supplying $12 \%$ protein and $20 \%$ sunflower seed oil. Soy was chosen as the protein source because of its ready availability and its supposed inhibitory effect on various types of cancers in animals (6).

\section{MATERIALS AND METHODS}

Animals/diets. A total of 48 weanling male Sprague-Dawley rats $(70 \mathrm{~g})$ were purchased from Animal Resource Centre, Murdoch University, Perth, Australia. The animals were housed in stainless steel wire-bottom cages, maintained in an air-conditioned environment $23^{\circ} \mathrm{C}$ with a 12 -h light: 12 -h dark cycle. Rats at the age of 4 weeks were randomly divided into eight groups of six animals each and fed ad libitum experimental powdered diets and given free access to deionized water for eight weeks. Body weights were recorded weekly. Each rat was placed in a metabolic cage for $48 \mathrm{~h}$ in the seventh week on an experimental diet. Food intake and fecal and urine outputs were recorded.

The experimental diets were modified forms of the AIN (5) semipurified diet. They consisted of $12 \%$ protein (either casein $(80 \%$ protein) or soy protein isolate ( $85 \%$ protein), Protein Technologies International, St. Louis, MO), 5\% cellulose as dietary fiber, $35 \%$ starch, $20 \%$ sunflower seed oil as the fat source, $20 \%$ sucrose, $3.5 \%$ AIN-76A minerals, and $1 \%$ AIN-76A vitamins. The nutrient-replete diets contained $2 \mathrm{mg} / \mathrm{kg}$ folic acid, $0.2 \%$ choline, and $0.4 \%$ methionine. The diet lacking only folate was (FD); diets lacking folate and choline were (FCD); and the diets lacking folate, choline, and methionine were (FCMD).

Casein as a protein source contained $0.045 \mathrm{mg} / \mathrm{kg}$ endogenous folate, and soy protein isolate contained $1.28 \mathrm{mg} / \mathrm{kg}$ endogenous folate, when analyzed by the 
Lactobacillus casei assay (Chemistry Centre, WA).

This experimental protocol was approved by the Animal Experimentation and Ethics Committee in the CSIRO, Division of Human Nutrition, before commencing the work.

Sample collection. After the rats were on experimental diets for 4 weeks, blood samples were collected via the tail vein under ether anesthesia. Blood was collected in EDTA tubes and immediately diluted $1: 1$ with fresh $1 \%$ ascorbic acid and stored at $-80^{\circ} \mathrm{C}$ for folate determinations. The rats were killed by exsanguination under ether anesthesia after 8 weeks on experimental diets, blood was collected into EDTA tubes, and a portion was diluted with $1 \%$ ascorbic acid for folate analyses. The remaining blood was centrifuged at $1,000 \times g$ for $10 \mathrm{~min}$, and plasma was collected and stored at $-80^{\circ} \mathrm{C}$ for subsequent homocysteine measurements. Livers were excised, weighed, and frozen in liquid nitrogen and stored at $-80^{\circ} \mathrm{C}$ for subsequent DNA extraction.

Analytical methods. Whole blood folate was determined by HPLC with fluorescence detection (7). Total plasma homocysteine was measured by HPLC by using the fluorometric method of Vester and Rasmussen (8).

The DNA from liver and colonic mucosal scrapings was isolated by using a High Pure PCR Template preparation kit (Boehringer Mannheim) followed by treatment with $10 \mathrm{mg} / \mathrm{mL}$ solution of RNAse that had been preheated to $100^{\circ} \mathrm{C}$ for $15 \mathrm{~min}$ and cooled slowly to room temperature. The purified DNA was then hydrolyzed with formic acid, and the individual nucleobases were determined by using HPLC (9) to measure the level of DNA methylation. The percentage of methylation was calculated from the content of 5-methylcytosine over 5methylcytosine plus cytosine content multiplied by 100 .

Statistical analysis. The GraphPad Instat software package (version 2; San Diego, CA, USA) was used for statistical analysis of experimental data. The statistical significance of the mean values was tested by one-way analysis of variance with the criterion for significance taken at $p<0.05$. The differences between the means were then subjected to the Tukey-Kramer multiple comparison test with significance obtained at $p<0.05$.

\section{RESULTS}

The mean daily food consumption of the animals fed the different dietary treatments were as follows (mean $\pm \mathrm{SE}$ ): casein, $17.4 \pm 0.7 \mathrm{~g}$; casein/FD, $16.2 \pm$ $0.8 \mathrm{~g}$; casein/FCD, $17.8 \pm 0.9 \mathrm{~g} ;$ casein/FCMD, $18.0 \pm 0.5 \mathrm{~g} ; \quad \mathrm{SPI}, 14.5 \pm 0.9 \mathrm{~g}$; SPI/FD, $15.5 \pm 0.4 \mathrm{~g}$; SPI/FCD, $14.1 \pm 0.5 \mathrm{~g}$; SPI/FCMD, $14.0 \pm 0.8 \mathrm{~g}$. Depleting the experimental diets of folate, choline, and methionine had no significant effect on the food intake of the animals. However, the rats fed the casein background diets consumed significantly more food per day $(3 \mathrm{~g} / \mathrm{d})(p<0.001)$.

The casein-fed animals were significantly heavier than the SPI-fed animals at the time of death $(p<0.001)$. A dietary lack of folate and choline had no influence 
Table 1. Effect of folate, choline, and methionine deficiencies on whole blood folate concentration and hematocrit in rats fed casein or SPI diets deficient in folate, choline, and methionine.

\begin{tabular}{lcccc}
\hline \multicolumn{1}{c}{ Group } & $\begin{array}{c}\text { Whole blood folate } \\
(4 \text { weeks })\end{array}$ & $\begin{array}{c}\text { Hematocrit } \\
(8 \text { weeks })\end{array}$ & $\begin{array}{c}\text { Plasma } \\
(\% \text { weeks }) \\
(\% \text { red cells })\end{array}$ & $\begin{array}{c}\text { homocysteine } \\
(8 \text { weeks }) \\
(\mu \mathrm{M})\end{array}$ \\
\hline Casein (cas) & $613 \pm 43^{\mathrm{a}}$ & $584 \pm 23^{\mathrm{a}}$ & $41.9 \pm 0.40^{\mathrm{a}}$ & $1.29 \pm 0.07^{\mathrm{d}}$ \\
cas/FD & $226 \pm 25^{\mathrm{c}}$ & $186 \pm 8^{\mathrm{d}}$ & $41.0 \pm 0.37^{\mathrm{a}}$ & $3.64 \pm 0.18^{\mathrm{c}}$ \\
cas/FCD & $254 \pm 27^{\mathrm{bc}}$ & $172 \pm 4^{\mathrm{d}}$ & $40.8 \pm 0.40^{\mathrm{a}}$ & $8.75 \pm 1.02^{\mathrm{b}}$ \\
cas/FCMD & $273 \pm 28^{\mathrm{bc}}$ & $195 \pm 7^{\mathrm{d}}$ & $38.5 \pm 0.42^{\mathrm{b}}$ & $11.34 \pm 0.70^{\mathrm{a}}$ \\
SPI & $583 \pm 42^{\mathrm{a}}$ & $612 \pm 22^{\mathrm{a}}$ & $41.2 \pm 0.40^{\mathrm{a}}$ & $1.26 \pm 0.07^{\mathrm{d}}$ \\
SPI/FD & $404 \pm 18^{\mathrm{b}}$ & $300 \pm 4^{\mathrm{c}}$ & $40.4 \pm 0.56^{\mathrm{ab}}$ & $1.62 \pm 0.14^{\mathrm{cd}}$ \\
SPI/FCD & $406 \pm 26^{\mathrm{b}}$ & $409 \pm 27^{\mathrm{b}}$ & $41.2 \pm 0.40^{\mathrm{a}}$ & $2.58 \pm 0.26^{\mathrm{cd}}$ \\
SPI/FCMD & $384 \pm 36^{\mathrm{b}}$ & $437 \pm 17^{\mathrm{b}}$ & $40.7 \pm 0.49^{\mathrm{a}}$ & $1.81 \pm 0.25^{\text {cd }}$ \\
\hline
\end{tabular}

Values are means $\pm \mathrm{SE}$ for six rats. Values within each column with different superscript letters are significantly different $(p<0.05)$.

FD, folate-deficient; FCD-folate, choline-deficient; FCMD, folate-, choline-, methioninedeficient.

on the growth of the experimental animals. A lack of dietary methionine resulted in significantly reduced weight gains in both casein- and SPI-fed animals. This was more evident with the SPI treatment (33\% fall) compared with the casein treatments $(10 \%$ fall).

Table 1 shows the effect of feeding rats methyl-deficient experimental diets on whole blood folate concentration after 4 and 8 weeks. After 4 weeks, a significant depletion of folate concentrations was evident. In the casein-fed animals, folate concentrations fell $60 \%$, and in the SPI-fed animals a fall of $32 \%$ was observed when compared with their control treatments. Feeding the diets for a further 4 weeks (total of 8 weeks) resulted in only minor additional reductions in folate concentrations. Depleting the diets progressively with choline and methionine on top of the folate deficit seemed to have no additional effect on the folate status in the whole blood.

Hematocrit values (Table 1) showed that the rats fed the casein/FCMD diet had a significantly $(p<0.05)$ lower hematocrit than those fed all other diets, except the SPI/FD diet. However, despite a halving of folate levels, changes in hematocrit were small.

Plasma homocysteine concentrations (Table 1) were significantly elevated $(p<0.0001)$ in the casein rats that were fed diets depleted of methyl groups. A significant negative correlation was observed in the casein-fed rats between plasma homocysteine concentration and decreasing methyl content of the diet $\left(r^{2}=0.978\right.$, $p<0.002)$. Neither a significant correlation nor an elevation of plasma homocysteine 
Table 2. Percentage of 5-methylcytosine in hepatic DNA.

\begin{tabular}{lc}
\hline Group & $\%$ 5-methylcytosine \\
\hline Casein (cas) & $3.703 \pm 0.030^{\mathrm{a}}$ \\
cas/FD & $3.304 \pm 0.191^{\mathrm{ab}}$ \\
cas/FCD & $2.934 \pm 0.141^{\mathrm{b}}$ \\
cas/FCMD & $2.900 \pm 0.151^{\mathrm{b}}$ \\
SPI & $3.347 \pm 0.132^{\mathrm{ab}}$ \\
SPI/FD & $3.411 \pm 0.169^{\mathrm{ab}}$ \\
SPI/FCD & $3.397 \pm 0.100^{\mathrm{ab}}$ \\
SPI/FCMD & $3.206 \pm 0.100^{\mathrm{b}}$
\end{tabular}

Values are means \pm SE for six rats. Values in the same column not sharing a common superscript letter are significantly different.

SPI, soy protein isolate; FD, folate-deficient; FCD, folate-, choline-deficient; FCMD, folate-, choline-, methionine-deficient.

was observed with the corresponding SPI treatments.

The percentage of 5-methylcytosine content in hepatic DNA is shown in Table 2. Hypomethylation of DNA, that is, a decrease in the level of 5-methylcytosine, was observed in the casein groups with lowered folate status. This observation was significant $(p<0.05)$ in the casein treatments depleted of FCD and FCMD with over a fall in methylation of more than $20 \%$. No significant change was noted in methylation relative to control in the SPI-fed rats.

\section{DISCUSSION}

This study showed that folate status can be significantly reduced after only four weeks of feeding a semipurified diet depleted of the B-vitamin folate. The degree of folate depletion is within the range reported by other researchers $(10,11)$ and would be regarded as a moderate folate depletion because hematocrits were affected only marginally. The failure to produce significant hematological change is consistent with the knowledge that the rat is resistant to such change relative to some other species studied (12).

The level of folate depletion achieved was significantly greater in the casein-fed rats consuming methyl-deficient diets than in the corresponding SPI-fed rats. This most likely reflects the much higher amount of endogenous folate present within the soy protein isolate $(1.28 \mathrm{mg} / \mathrm{kg}$ compared with $0.045 \mathrm{mg} / \mathrm{kg}$ for casein). Although the sulfur amino acid content of the diets was balanced, the casein fed rats had a much greater body weight gain over the 8-week period compared with the SPI-fed rats. This indicates that casein is a superior quality protein to SPI for rat growth and is most likely attributable to a higher content of the essential amino acids isoleucine and threonine (13).

Homocysteine concentration in the plasma was significantly elevated in the 
casein treatments, which were fed deficient levels of folate, and in the treatments with choline and methionine deficiencies superimposed. Interestingly, homocysteine levels were not increased in any of the SPI treatments. Plasma homocysteine levels have been shown by other researchers to be inversely correlated with intracellular folate because of the requirement of folate and its coenzymes (11). The remethylation of homocysteine to methionine is dependent on two main pathways. The first requires folate and its coenzymes with vitamin B-12 containing 5-methyl-tetrahydrofolate : homocysteine methyltransferase catalyzing the reaction (14). The other pathway in which homocysteine is remethylated uses choline. Here choline is oxidized to betaine, which serves as the methyl donor in a reaction catalyzed by betaine: homocysteine methyltransferase (15). The occurrence of hyperhomocysteinemia in the casein rats depleted of dietary methyl groups suggests that a functional or biochemical deficiency is present within these treatments and that a disruption in one or both of the above pathways has occurred. Since plasma homocysteine levels were not significantly elevated in the SPI treatments fed depleted methyl groups, even though blood folate levels were depleted, it suggests that endogenous factor(s) are within SPI preventing a functional deficiency of folate. The most obvious factor is folate; it was present in SPI at more than 28 times the concentration of the casein. The elevation of plasma homocysteine observed in the casein-fed rats depleted of folate, choline, and methionine may also be of importance in terms of risk of cardiovascular disease. Elevated levels of plasma homocysteine have been identified as being an independent risk factor for premature vascular disease (16).

A disruption of the transmethylation cycle in the liver resulted in hypomethylation of DNA in the casein-fed rats. This decrease in methylation was not observed in the corresponding SPI-treated rats, which also had a lesser degree of folate depletion. Altered DNA methylation has been proposed as an early step in the multistep process of tumorigenesis, and changes in DNA methylation can lead to altered regulation of gene expression (4). The induction of DNA hypomethylation could then be a mechanism by which diminished folate status acts to enhance carcinogenesis (17). Global and gene-specific hypomethylation of hepatic DNA has been observed in rats fed methyl-deficient diets $(18,19)$. The data presented here confirm that a dietary folate deficit alone was unable to alter DNA methylation significantly within the time frame studied. When choline and methionine deficits from the diet were superimposed on a folate deficit, however, the induction of hypomethylation of hepatic DNA was observed.

In summary, the present study has demonstrated that diets depleted of folate can lower folate status. Deficiencies of choline and methionine superimposed on a dietary folate deficit do not seem to influence blood folate status. Plasma homocysteine levels rose sharply in casein rats fed methyl-depleted diets, an observation not seen in SPI fed animals. Feeding an SPI diet to the rats was also allowed an adequate level of DNA methylation to be maintained during methyl group depletion. The type of dietary protein is important in influencing these metabolic parameters, which is probably a reflection of the amount of endogenous 
folate present within the protein source.

This research was supported by the Dairy Research Development Corp. We thank Dr. Michael Fenech for helpful comments and Mr. Peter Royle and Mr. Ben Scherer for technical assistance.

\section{REFERENCES}

1) Mikol YB, Hoover KL, Creasea D, Poirier LA. 1983. Hepatocarcinogenesis in rats fed methyl-deficient, amino acid-defined diets. Carcinogenesis 4: 1619-1629.

2) Giovannucci E, Stampfer MJ, Colditz GA, Rimm EB, Trichopoulos D, Rosner BA, Speizer FE, Willett WC. 1993. Folate, methionine and alcohol intake and risk of colorectal adenoma. JNCI 85: 875-883.

3) Feinberg AP, Gehrke CW, Kuo KC, Ehrlich M. 1988. Reduced genomic 5-methylcytosine in human colonic neoplasia. Cancer Res 48: 1159-1161.

4) Fearon ER, Vogelstein B. 1990. A genetic model for colorectal tumorigenesis. Cell 61: $759-767$.

5) American Institute of Nutrition. 1977. Report of the American Institute of Nutrition ad hoc committee on standards for nutritional studies. $J$ Nutr 107: 1340-1348.

6) Hawrylewicz EJ, Zapata JJ, Blair WH. 1995. Soy and experimental cancer: Animal studies. $J$ Nutr 125: 698s-708s.

7) Wigertz K, Jagerstad M. 1995. Comparison of a HPLC and radioprotein-binding assay for the determination of folates in milk and blood samples. Food Chem 54: 429-436.

8) Vester B, Rasmussen K. 1991. High performance liquid chromatography method for rapid and accurate determination of homocysteine in plasma and serum. Eur J Clin Biochem 29: 549-554.

9) Corvetta A, Bitta RD, Luchetti M, Pomponio G. 1991. 5-Methylcytosine content of DNA in blood, synovial mononuclear cells and synovial tissue from patients affected by autoimmune rheumatic diseases. J Chromatogr 566: 481-491.

10) Cravo M, Mason J, Dayal Y, Smith D, Selhub J, Rosenberg I. 1992. Folate deficiency enhances the development of colonic neoplasia in dimethylhydrazine-treated rats. Cancer Res 52: 5002-5006.

11) Kim YI, Salomon RN, Cook FG, Choi SW, Smith DE, Dallal GE, Mason JB. 1996. Dietary folate protects against the development of macroscopic colonic neoplasia in a dose responsive manner in rats. Gut 39: 732-740.

12) Friedrich W. 1988. Folic acid and unconjugated pteridines. In: Vitamins, p 619-752. Walter de Gruyter, Berlin, New York.

13) Yoshida A. 1990. Amino acid requirement of experimental rats. In: Nutrition: Proteins and Amino Acids (Yoshida A, Naito H, Niiyama Y, Suzuki T, eds), p 97-106. Japan Sci. Soc. Press, Tokyo/Springer-Verlag, Berlin.

14) Selhub J, Miller JW. 1992. The pathogenesis of hyperhomocysteinemia: interruption of the coordinate regulation by S-adenosylmethionine of the remethylation and transulfuration of homocysteine. Am J Clin Nutr 55: 131-138.

15) Finkelstein JD, Martin JJ, Harris BJ, Kyle WE. 1982. Regulation of betaine content of rat liver. Arch Biochem Acta 260: 259-271.

16) Kang SS, Wong PWK, Malinow MR. 1992. Hyperhomocyst(e)inemia as a risk factor for occlusive vascular disease. Ann Rev Nutr 12: 279-298.

17) Mason JB. 1994. Folate and colonic carcinogenesis: searching for a mechanistic

Vol 44, No 3, 1998 
understanding. J Nutr Biochem 5: 170-175.

18) Wainfan E, Dizik M, Stender M, Christman JK. 1989. Rapid appearance of hypomethylated DNA in livers of rats fed cancer-promoting methyl-deficient diets. Cancer Res 49: 4094-4097.

19) Kim YI, Progribny IP, Basnakian AG, Miller JM, Selhub J, James SJ, Mason JB. 1997. Folate deficiency in rats induces DNA strand breaks and hypomethylation within the p53 tumor suppressor gene. Am J Clin Nutr 65: 46-52. 